\title{
Potensi Usaha Kuliner Asli Daerah dalam Menunjang Pariwisata di Provinsi Bengkulu
}

\author{
Suswati Nasution ${ }^{1}$, Rinto Noviantoro ${ }^{2}$ \\ Fakultas Ekonomi, Universitas Dahasen Bengkulu \\ Jalan Meranti Raya No.32 Sawah Lebar Bengkulu \\ suswatinasution@unived.ac.id \\ noviantororinto@gmail.com
}

\begin{abstract}
Abstrak- Penelitian ini menganalisis potensi usaha kuliner asli daerah dalam menunjang pariwisata di Provinsi Bengkulu. Dalam menganalisis potensi tersebut, penelitian difokuskan pada beberapa daerah wisata yang ada di Provinsi Bengkulu, dengan melihat perkembangan usaha kuliner yang meramaikan objek wisata yang diteliti. Tujuan dari penelitian ini yaitu untuk mengetahui strategi yang di terapkan pengusaha makanan asli daerah agar makanan yang di produksinya dapat dikenal secara luas di masyarakat serta berperan dalam menunjang perkembangan pariwisata di Provinsi Bengkulu. Penelitian ini bersifat penelitian deskriptif (descriptive research) dengan menggunakan data primer dan sekunder. Metode analisa data adalah deskriptif kualitatif. Dalam melakukan analisa data dilakukan dengan mengumpulkan data sekunder maupun data primer. Data sekunder diperoleh dari Pemerintah Provinsi Bengkulu, Dinas Pariwisata Provinsi Bengkulu dan Biro Pusat Statistik. Data primer diperoleh dengan mewawancarai langsung dengan pengunjung wisata, pedagang atau pengusaha makanan khas daerah Bengkulu. Alat analisis yang digunakan adalah analisis dengan metode SWOT.
\end{abstract}

Kata Kunci- pariwisata; strategi; usaha

\begin{abstract}
This study is concerned with the potentials of indigenous culinary businesses in several tourist areas in Bengkulu. Using a descriptive approach, we look at the development of culinary industry in the research locus aiming to find out the strategies applied by local culinary entrepreneurs to introduce their indigenous culinary so as to support the regional tourism development in general. Primary research data were collected through intreviews with tourists and culinary business owners at the research locus. Secondary research data were obtained from Bengkulu Regional Adminstration Office, Bengkulu Tourism Office, and Statistics Bureau of Bengku. These data were analyzed using SWOT analysis method.
\end{abstract}

Keywords: indigenous culinary business, culinary tourism, SWOT.

\section{PENDAHULUAN}

Bengkulu merupakan salah satu Provinsi di Sumatera yang sedang bergiat menggalakkan dan mengembangkan potensi pariwisata yang dimilikinya. Berbagai upaya sedang di lakukan pemerintah daerah agar objek wisata yang ada di Propinsi Bengkulu makin ramai dikunjungi para wisatawan, baik wisatawan lokal, nasional maupun internasional. Dukungan masyarakat, sangat diperlukan dalam upaya peningkatan kunjungan wisatawan ini, selama ini masyarakat memang dituntut untuk berpartisipasi nyata dalam menggalakkan geliat sektor pariwisata, peran masyarakat dapat terlihat dengan makin banyaknya gerai yang menunjang pariwisata seperti, kedai makanan, kedai souvenir, kedai pakaian, maupun pernak-pernik yang membuat betah wisatawan untuk berkunjung dan datang kembali ke Bengkulu.

Salah satu hal menarik yang tidak terlepas dari perkembangan pariwisata adalah wisata kuliner, dimana wisatawan tidak puas jika belum menikmati sajian kuliner di daerah yang mereka kunjungi. Makanan asli daerah atau khas daerah, masih menjadi primadona untuk disantap maupun untuk dibawa sebagai oleh-oleh, seperti yang sudah kita kenal misalnya aneka kerupuk olahan ubi (salah satunya kerupuk sanjai) yang merupakan cemilan khas daerah Padang Sumatera Barat, serta berbagai santapan makanan salah satunya sate khas Padang, bakpia dan santapan gudeg khas Jogyakarta, peuyem oleh-oleh khas Bandung, empek-empek dari palembang. Dan masih banyak lagi dari daerah lain, yang apabila disebutkan nama makanannya orang langsung tahu dari mana makanan tersebut berasal.

Ciri khas daerah ini juga dapat kita jumpai pada rumah makan yang menyajikan menu khas daerah yang tentunya bertujuan menggoyang lidah para wisatawan. Makanan khas daerah yang terkenal menggoyang lidah di Propinsi Bengkulu banyak ragamnya, diantaranya: lempok durian, dodol durian, pulut punai, kue tat, kue cucur, kopi asli Bengkulu, beragam makanan olahan ikan laut dan minuman khas Bengkulu jeruk kalamansi dan sari jahe merah. Sedangkan rumah makan yang menyajikan makanan khas Bengkulu jumlahnya masih sangat kecil, makanan khas yang biasa disajikan diantaranya adalah gulai tempoyak, gulai ikan beraneka jenis, rendang lokan, sate gurita, rebung asam, sayur pakis, ikan kemukus, pendap dan menu khas Bengkulu lainnya. 
Kesemua makanan ini memiliki potensi yang sangat besar yang dapat memancing rasa kangen wisatawan untuk datang dan kembali berkunjung ke Propinsi Bengkulu.

Berdasarkan laporan dari World Trade and Tourism Council (WTTC) tahun 2018 bahwa sektor pariwisata Indonesia mencatat pertumbuhan tertinggi dengan menduduki peringkat ke-9 di dunia [1]. Analisis SWOT terhadap potensi usaha kuliner asli daerah yang menunjang pariwisata, akan menghasilkan keunggulan diantara berbagai jenis usaha kuliner yang ada untuk kemudian lebih difokuskan dan dipromosikan sebagai ciri khas daerah, sehingga wisatawan langsung tahu, jika disebutkan tempat asal atau makanan tersebut darimana, mereka bisa tahu dari daerah mana makanan tersebut berasal. Bagaimana strategi yang diterapkan pengusaha makanan asli daerah agar usaha makanan yang dijalankan dapat dikenal luas dan menunjang perkembangan pariwisata di Provinsi Bengkulu.

\section{KAJIAN PUSTAKA}

\section{Usaha}

Usaha adalah kegiatan dengan mengerahkan tenaga dan pikiran untuk mencapai suatu maksud, atau mencari keuntungan, berusaha dan Bekerja dengan giat untuk mencapai sesuatu[2]. Secara umum usaha diartikan sebagai suatu kegiatan yang dilakukan oleh manusia untuk memperoleh pendapatan atau penghasilan atau rezeki dalam rangka memenuhi kebutuhan dan keinginan hidupnya dengan cara mengelola sumber daya ekonomi secara efektif dan efisien. Dalam usaha terdapat dua kegiatan yaitu produksi dan pemasaran. Produksi merupakan hasil usaha manusia yang menciptakan barang yang tidak ada menjadi ada, atau disebut juga dengan mengadakan perubahan bentuk atau mengembangkan bahan-bahan alam sehingga akhirnya memiliki sifat yang dapat memenuhi kebutuhan hidup manusia.

Faktor-faktor yang menyebabkan keberhasilan usaha, adalah: peluang, manusia, keuangan, pemasaran dan penjualan, administrasi dan peraturan (pemerintah, politik, sosial, ekonomi dan budaya local). Sedangkan faktor-faktor yang menyebabkan kegagalan usaha, adalah: data dan informasi tidak lengkap, tidak teliti, lokasi kurang menguntungkan, membeli barang telalu banyak, kurang mengawasi persediaan barang.

Usaha yang dirintis harus memiliki prospek yang cerah kedepannya. Dalam kamus besar bahasa indonesia prospek adalah peluang atau harapan, pandangan (kedepan), pengharapan (memberi), harapan baik, kemungkinan. Prospek merupakan gambaran umum tentang usaha yang kita jalankan untuk masa yang akan datang. Keberhasilan suatu usaha tergantung dari faktor-faktor pengusaha itu sendiri, baik dari dalam maupun dari luar. Faktor dari dalam seperti pengelolaan, tenaga kerja, modal, tingkat tekhnologi, dan lain sebagainya. Sedangkan faktor dari luar seperti tersedianya sarana transportasi dan komunikasi. Dalam ilmu ekonomi prospek merupakan gambaran untuk masa yang akan datang, apakah usaha yang kita jalankan itu akan berjalan dengan lancar dan mendapatkan keuntungan atau malah sebaliknya karena tidak adanya permintaan atau tidak adanya promosi sehingga konsumen tidak mengetahui keberadaan produk yang dihasilkan.

\section{Strategi}

Dalam melihat potensi suatu usaha, diperlukan suatu strategi yang menganalisa berbagai hal yang berkaitan dengan usaha. Mencakup Analisa lingkungan internal dan ekternal. Analisa lingkungan internal merupakan suatu proses untuk menilai faktorfaktor keunggulan strategis organisasi/perusahaan, mencari faktor-faktor yang penghambat dan mendukung strategi pengembangan, sehingga penyusunan strategi dapat dimanfaatkan secara efektif. Konsep srategi dapat didefinisikan berdasarkan dua perspektif yang berbeda yaitu dari perspektif apa yang ingin dilakukan oleh suatu organisasi (interns to do) dan dari perspektif apa yang akhirnya dilakukan oleh organisasi (eventuality does).

Bila konsep strategi tidak jelas, maka keputusan yang diambil mungkin akan bersifat subyektif berdasarkan intuisi belaka dan mengabaikan keputusan yang lain. Strategi merupakan alat yang sangat dibutuhkan untuk mencapai tujuan dalam keadaan masa depan yang tidak pasti dan tidak jelas. Dengan Strategi kita dapat meminimalkan kemungkinan kegagalan dan memaksimalkan keberhasilan dalam mencapai tujuan.

Pimpinan suatu organisasi setiap hari berusaha mencari kesesuaian antara kekuatan-kekuatan internal dan kekuatan-kekuatan eksternal (peluang dan ancaman) [3]. Kegiatannya meliputi pengamatan secara hati-hati persaingan, peraturan, tingkat inflasi, siklus bisnis, keinginan dan harapan konsumen serta faktor-faktor lain yang dapat mengindentifikasi peluang dan ancaman. Dapat dilihat perbedaan konsep mengenai strategi selama 30 tahun terakhir. Lingkungan internal merupakan suatu proses untuk menialai faktor-faktor keunggulan strategis organisasi untuk menentukan dimana kekuatan dan kelemahannya, sehingga penyusunan strategi dapat dimanfaatkan secara efektif, kesempatan lingkungan 
dan menghadapi hambatannya. Mengembangkan profil sumberdaya dan keunggulan, membandingkan profil tersebut dengan kunci sukses, dan mengindentifikasi kekuatan utama dimana industri dapat membangun strategi untuk mengeksploitasi peluang dan meminimalkan kelemahan dan mencegah kegagalan.

Kondisi lingkungan eksternal yang tidak pasti mengharuskan organisasi menyusun strategi yang tepat terhadap pengembangan investasi bisnis, karena lingkungan eksternal tersebut sebagian besar tidak dapat dikendalikan, menganjurkan langkah-langkah yang perlu diambil untuk memperkirakan peluang serta ancaman lingkungan eksternal adalah mengindentifikasi faktor-faktor lingkungan, mengamati perubahan secara global.

\section{Pariwisata}

Pendapatan konsumen, persepsi fasilitas wisata dan selera konsumen mempunyai pengaruh positif terhadap permintaan jasa pariwisata [4]. Menurut Lundberg dalam [5], kepariwisataan adalah orangorang yang melakukan perjalanan pergi dari rumahnya dan perusahaan-perusahaan yang melayani dengan cara memperlancar atau mempermudah perjalanan atau membuatnya lebih menyenangkan. Sebagai suatu konsep, pariwisata dapat ditinjau dari berbagai segi yang berbeda. Pariwisata dapat dilihat sebagai suatu kegiatan melakukan perjalanan dari rumah dengan maksud tidak melakukan usaha atau hanya kegiatan bersantai. Undang-Undang Republik Indonesia Nomor 9 Tahun 1990 Pasal 1 [6], pariwisata adalah segala sesuatu yang berhubungan dengan wisata, termasuk pengusahaan ojek dan daya tarik wisata serta usahausaha yang terkait dibidang tersebut. Dengan demikian pariwisata meliputi hal-hal berikut:

1. Semua kegiatan yang berhubungan dengan perjalanan wisata.

2. Pengusahaan objek wisata dan daya tarik wisata seperti kawasan wisata, taman rekreasi, kawasan peninggalan sejarah, museum, waduk, pergelaran seni dan budaya, tata kehidupan masyarakat, dan bersifat alamiah seperti keindahan alam, gunung berapi, danau, pantai indah dan sebagainya

3. Pengusahaan jasa dan sarana pariwisata yaitu usaha jasa pariwisata, usaha sarana wisata ( akomodasi, rumah makan, bar, angkutan wisata, kerajinan daerah) dan usaha-usaha yang berkaitan dengan penyelenggaraan pariwisata.

\section{METODE PENELITIAN}

Jenis penelitian yang digunakan merupakan penelitian deskriptif. Fenomena itu bisa berupa bentuk, aktivitas, karakteristik, perubahan, hubungan, kesamaan, dan perbedaan antara fenomena yang satu dengan fenomena lainnya. Penelitian deskriptif digunakan untuk menganalisa data dengan cara mendeskripsikan atau menggambarkan data yang telah terkumpul sebagai mana adanya tanpa bermaksud membuat kesimpulan secara umum [2]. Sumber data penelitian ini terdiri dari data primer dan data sekunder yang dikumpulkan dengan cara/tehnik sebagai berikut:

1. Teknik Observasi, yaitu dengan melakukan pengamatan langsung keadaan objek di lapangan, yaitu faktor-faktor Analisis Potensi Usaha Kuliner Asli Daerah Dalam Menunjang Pariwisata Di Provinsi Bengkulu.

2. Teknik Kuesioner (data primer), yaitu teknik pengumpulan data dan informasi dengan cara mengajukan daftar pertanyaan secara tertulis yang bersifat tertutup karena pilihan jawaban telah ditentukan kepada orang yang menjadi responden.

Pengambilan data sekunder diperoleh melalui dokumentasi, yaitu dengan melakukan pengkajian terhadap data-data yang tersedia seperti Dinas Pariwisata Provinsi Bengkulu, buku, literatur, jurnal, laporan dan informasi resmi lembaga negara (Badan Pusat Statistik) maupun yang diakses melalui internet. Sampel adalah bagian dari populasi (sebagian atau wakil populasi yang diteliti) [7]. Sampel penelitian adalah sebagian dari populasi yang diambil sebagai sumber data dan dapat mewakili seluruh populasi. Sampling berarti mengambil sampel atau mengambil sesuatu bagian populasi atau semesta sebagai wakil (respresentasi) populasi atas semesta itu [7]. Yang dijadikan sampel pada penelitian ini adalah:

1. Faktor internal responden terdiri dari 50 orang pengusaha kuliner, 20 orang Dinas Pariwisata, 30 orang masyarakat yang berdomisili sekitar daerah wisata dan 80 orang wisatawan.

2. Faktor Eksternal Responden terdiri dari 20 orang wisatan luar Bengkulu.

Adapun metode yang digunakan adalah metode accidental sampling yaitu metode pengambilan sampel dengan cara menentukan responden sesuai dengan tujuan yang akan diteliti.

\section{Variabel Penelitian}

Variabel yang akan diteliti dari potensi usaha kuliner asli daerah diantaranya adalah makanan khas dari laut, makanan khas olahan dari laut, makanan khas olahan dari tepung, makanan khas olahan dari buah (Variabel Bebas). Dimana dari sekian banyak makanan tersebut mana makanan yang paling berpengaruh dalam menunjang pariwisata di Provinsi Bengkulu (Variabel terikat). 
Tabel 1. Data Populasi dan Sampel Penelitian

\begin{tabular}{lcc}
\hline \multicolumn{1}{c}{ Informan } & $\begin{array}{c}\text { Populasi } \\
\text { (orang) }\end{array}$ & $\begin{array}{c}\text { Sampel } \\
\text { (orang) }\end{array}$ \\
\hline $\begin{array}{l}\text { Pengusaha } \\
\text { Kuliner }\end{array}$ & 100 & 50 orang \\
\hline Dinas Pariwisata & 50 & 20 orang \\
\hline $\begin{array}{l}\text { Masyarakat } \\
\text { sekitar }\end{array}$ & 100 & 30 Orang \\
\hline $\begin{array}{l}\text { Wisatawan } \\
\text { Domestik }\end{array}$ & 200 & 80 orang \\
$\begin{array}{l}\text { Wisatawan Luar } \\
\text { Daerah }\end{array}$ & 50 & 20 orang \\
\hline \multicolumn{1}{c}{ JUMLAH } & 200 orang \\
\hline \begin{tabular}{l} 
Sumber: Hasil olahan peneliti berdasarkan teknik kuota sampling (2018) \\
\hline
\end{tabular}
\end{tabular}

\section{Definisi Operasional}

1. Potensi Usaha adalah segala hal yang dapat digali oleh para pelaku usaha untuk meningkatkan pendapatannya dalam memperluas usaha.

2. SWOT (strength-weakness-opportunity-treath) adalah suatu teknik analisis yang digunakan untuk mengidentifikasi kondisi internal (kekuatan dan kelemahan), dan kondisi eksternal (peluang dan ancaman) yang diterapkan para pengusaha untuk menggali potensi usaha yang ada.

3. Kekuatan merupakan setiap faktor/kondisi positif yang berasal dari dalam (Internal) yang mempunyai daya dukung yang kuat dalam menunjang upaya peningkatan usaha kuliner asli daerah.

4. Kelemahan merupakan setiap faktor/kondisi negatif yang berasal dari dalam (Internal) yang menghambat upaya Pencapaian peningkatan usaha kuliner.

5. Peluang merupakan setiap faktor/kondisi positif yang berasal dari luar (Eksternal) yang mendorong percepatan usaha.

6. Ancaman merupakan setiap faktor/kondisi negatif yang berasal dari luar (Eksternal) yang menghambat percepatan usaha.

\section{Sumber Data}

Sumber data Penelitian ini terdiri dari data primer dan data sekunder yang dikumpulkan dengan cara/teknik sebagai berikut:

1. Teknik Observasi, yaitu dengan melakukan pengamatan langsung keadaan objek di lapangan, yaitu faktor-faktor analisis potensi usaha kuliner asli daerah dalam menunjang pariwisata di Provinsi Bengkulu.

2. Teknik Kuesioner (data primer), yaitu teknik pengumpulan data dan informasi dengan cara mengajukan daftar pertanyaan secara tertulis yang bersifat tertutup karena pilihan jawaban telah ditentukan kepada orang yang menjadi responden.

Pengambilan data sekunder diperoleh melalui dokumentasi, yaitu dengan melakukan pengkajian terhadap data-data yang tersedia Dinas pariwisata Provinsi Bengkulu.

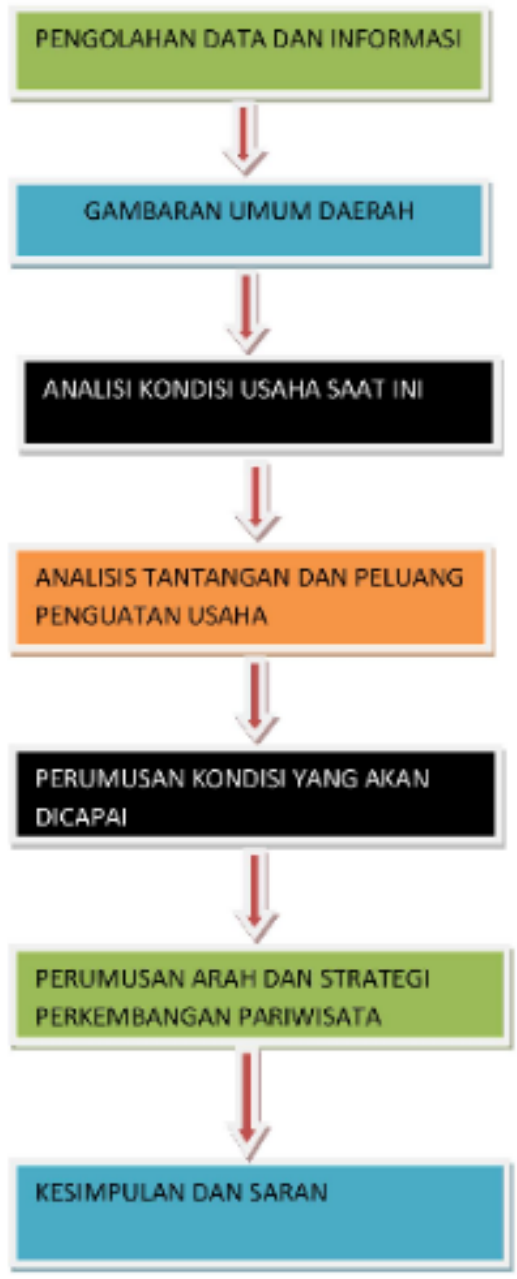

Sumber: Peneliti (2019)

Gambar 1. Diagram alur penelitian

\section{HASIL DAN PEMBAHASAN}

Provinsi Bengkulu terletak diantara $2^{\circ}-16^{\circ}-3^{\circ}-$ $31^{\circ}$ Lintang Selatan dan $101^{\circ}-110^{\circ}-103^{\circ}-41^{\circ}$ Bujur Timur, terletak di Pantai Barat Pulau Sumatera, Provinsi ini dilintasi oleh pegunungan Bukit Barisan yang membujur dari Utara hingga bagian Selatan Pulau Sumatera.

1. Sebelah Utara, berbatasan dengan Provinsi Sumatera Barat.

2. Sebelah Selatan berbatasan dengan Lampung dan Samuderah Hindia.

3. Sebelah Barat berbatasan dengan Samudera Indonesia. 
4. Sebelah Timur berbatasan dengan Sumatera Selatan dan Jambi.

Provinsi Bengkulu dengan ibukotanya Bengkulu, berbatasan langsung dengan Samudera Indonesia, dengan garis pantai sepanjang $433 \mathrm{Km}$. Bagian Timur tanahnya berbukit-bukit dengan dataran tinggi yang subur, sedangkan bagian barat merupakan dataran rendah yang relatif sempit, dari utara ke Selatan di selang- selingi daerah yang bergelombang. Provinsi Bengkulu memiliki luas wilayah 1.978 .870 ha atau $19.788,7 \mathrm{Km}^{2}$, yang secara administrasi terdiri dari 9 Kabupaten dan 1 Kota yaitu Kab. Muko-Muko, Kab. Bengkulu Utara, Kab. Bengkulu Tengah, Kab. Lebong, Kab. Rejang, Lebong, Kab. Kepahiang, Kab. Seluma, Kab. Bengkulu Selatan, Kab. Kaur, dan Kota Bengkulu [8].

Potensi kuliner dalam menunjang pariwisata di Provinsi Bengkulu sangat menjanjikan dan mempunyai harapan memberikan kontribusi terhadap peningkatan pariwisata. Potensi usaha kuliner yang dapat dikembangkan diantaranya aneka jenis makanan laut, aneka olahan makanan kemasan dari laut, aneka olahan makanan kemasan dari buah-buahan lokal dan aneka makanan olahan kemasan yang terbuat dari tepung.

Makanan yang dijadikan oleh-oleh atau buah tangan para wisatawan baik yang datang dari daerah lain maupun wisatawan lokal sebagai tanda telah mengunjungi Kota Bengkulu dan daerah kabupaten diantaranya adalah sebagai berikut: lempok durian, kue tat, pulut punai, manisan terung, manisan tomat, manisan belimbing wuluh, sirup kalamansi, minuman jahe merah, rengginang, marning, kerupuk singkong, kerupuk ubi jalar, aneka gorengan/keripik ikan asin, rendang lokan, sate kerang, sate gurita, tempoyak, pendap, kopi bengkulu, dodol dan banyak lagi jenis makanan yang potensinya masih bisa digali baik yang sudah ada maupun yang belum ada untuk dilakukan inovasi.

Sedangkan objek wisata yang ada di Provinsi Bengkulu yaitu:

1. Kota Bengkulu

Pantai Panjang, Pantai Berkas, Pantai Jakat, Kampung Cina, Tugu Hamilton, Rumah Fatmawati, British Cementary, Danau Dendam Tak Sudah, Danau Gedang Padang Betuah, Sungai Suci, Fort Marlborough, Makam Sentot Alibasyah, Mesjid Jamik, Monumen Thomas Parr, Museum Bengkulu, Rumah Sukarno, Tapak Paderi, dan Wisata Pulau Tikus.

2. Kabupaten Bengkulu Utara

Air Terjun Curug Sembilan, Air Terjun Kepala
Siring, Konservasi Gajah Seblat, dan Pulau Enggano.

3. Kabupaten Bengkulu Selatan

Pantai Muara Kedurang, Pantai Duayu Sekundang, Meriam Honisuit, Bendungan Air Nipis, Air Terjun Geluguran, dan Gua Suluman.

4. Kabupaten Bengkulu Tengah

Taman Liku Sembilan, Pantai Sungai Suci, Gunung Bungkuk, Bunker Coa Sako, dan Air Terjun Desa datar Lebar.

5. Kabupaten Rejang Lebong

Wisata taman bunga, Suban Air Panas, Lubuk Beso, Kebun Teh Bukit Danau, Diobagotte, Danau Harun Bastari, Bukit Kaba, Air Terjun Sindang Kelingi, dan Air Terjun Kepala Curup.

6. Kabupaten Lebong

Telaga Tujuh Warna, Lobang Kacamata, Danau Tes, Air Putih, dan Danau Picung.Wisata arung jeram arus bintuhan

7. Kabupaten Kepahiang

Tirta Muara Langkap, PLTA Musi, Perkebunan Teh Kabawetan, Konservasi Flora Raflesia Arnoldi, Konservasi Flora Amorphophallu, Danau Suro, Air Terjun Curug Embun dan air terjun kabawetan.

8. Kabupaten Mukomuko

Sungai Air Berau, Pantai Indah, Pantai Batung Bandoro, Pantai Air Rami, Dana Nibung, dan Air Majunto.

9. Kabupaten Seluma

Semidang Bukit Kabu, Pantai Seluma Goa Seluma, Bendungan Seluma, Ba Bekinyau, Arung Jeram Sungai Seluma dan Air Terjun Lubuk Resam.

10. Kabupaten Kaur

Pantai Way Hawang, Pantai Linau, dan Pantai Laguna Ujung Lancang.

Banyaknya tempat wisata yang ada, sebagian kondisinya masih sangat alami dan usaha kuliner belum mewarnai dan berkontribusi meramaikan daerah wisata. Dari berbagai tempat wisata, masyarakat belum banyak yang menyadari bahwa pengunjung atau wisatawan memerlukan panganan khas untuk bersantap ataupun membawa oleh-oleh sebagai buah tangan tanda berkunjung ke suatu daerah. Sehingga usaha kuliner yang dijadikan oleh-oleh tersebut akan memancing wisatawan lain untuk datang, terlebih beberapa tempat wisata di Provinsi Bengkulu sangat bagus dan tidak kalah menarik dibandingkan daerah lain yang ada di Indonesia, khususnya Sumatera. Hal tersebut tentunya dapat menunjang 
perkembangan pariwisata yang pada akhirnya akan meningkatkan pendapatan masyarakat setempat.

Perkembangan sektor pariwisata telah menjadi perhatian dalam pembangunan di provinsi Bengkulu. Hal tersebut tercermin dari kebijakan pemerintah daerah dalam menggali dan mengembangkan objek wisata yang ada di daerah. Dalam memperkenalkan dan menggalakkan wisata, pemerintah telah melakukan beberapa upaya seperti promosi wisata, pembangunan sarana dan prasarana menuju tempat wisata, dan penyediaan akomodasi yang memadai berupa hotel dan akomodasi lainnya.

Seiring dengan upaya yang telah dilakukan oleh pemerintah daerah, masih terdapat beberapa kendala terkait pengembangan sektor pariwisata di provinsi Bengkulu, salah satunya adalah kurangnya perkembangan kuliner yang ada, dimana kuliner adalah bagian menarik untuk membuat wisatawan datang kembali berkunjung.

Usaha kuliner yang tumbuh hanya meniru dan mempromosikan kuliner yang sudah ada dan berkembang. Berikut daftar tempat wisata dan kuliner yang mendominasi daerah wisata tersebut:

Tabel 2. Sata Lokasi Penelitian dan Ragam Kuliner

\begin{tabular}{|c|c|c|}
\hline $\begin{array}{l}\text { Daerah/ } \\
\text { Kabupaten }\end{array}$ & Tempat Wisata & Kuliner Khas Daerah \\
\hline Bengkulu Kota & $\begin{array}{ll}\text { 1. } & \text { Pantai Panjang } \\
\text { 2. } & \text { Pantai Berkas } \\
\text { 3. } & \text { Pantai jakat } \\
\text { 4. } & \text { Kampung Cina } \\
\text { 5. } & \text { Tugu Hamilton } \\
\text { 6. } & \text { Rumah Fatmawati } \\
\text { 7. } & \text { British Cementary } \\
\text { 8. } & \text { Danau Dendam Tak } \\
\text { 9. } & \text { Sudah } \\
\text { 9anau Gedang } \\
\text { 10. } & \text { Padang Betuah } \\
\text { 11. } & \text { Fort Marlborough } \\
\text { 12. } & \text { Makam Sentot } \\
\text { 13. } & \text { Alibasyah } \\
\text { 14. } & \text { Monjid Jamik } \\
\text { 15. } & \text { Parr } \\
\text { 16. } & \text { Ruman Thomas Bum Sukarno } \\
\text { 17. } & \text { Tapak Paderi } \\
\text { 18. } & \text { Wisata Pulau Tikus }\end{array}$ & 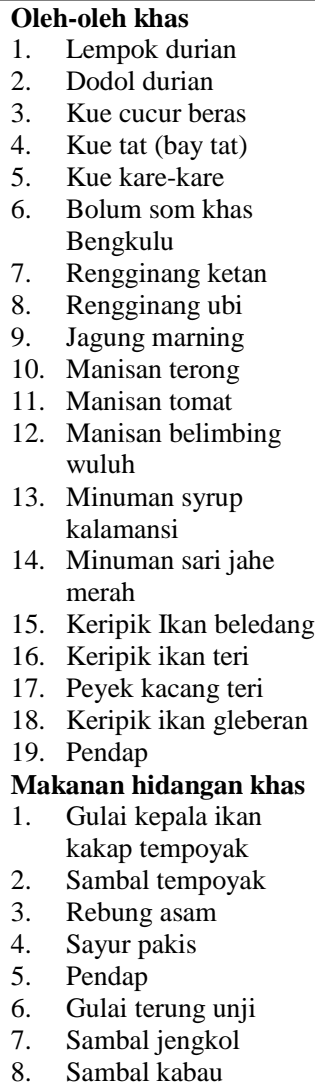 \\
\hline
\end{tabular}

\begin{tabular}{|c|c|c|}
\hline Muko-Muko & 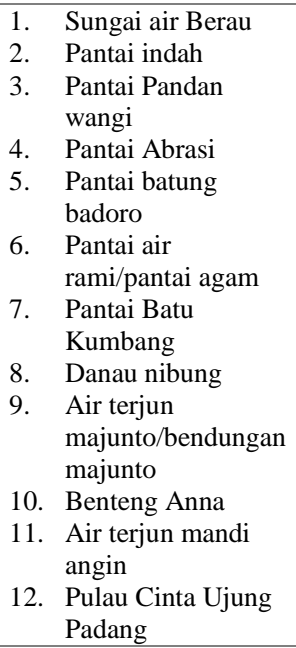 & $\begin{array}{l}\text { Oleh-oleh khas } \\
\text { 1. Kue tat khas muko- } \\
\quad \text { muko } \\
\text { 2. Pendap } \\
\text { 3. Kue lepek binti } \\
\text { 4. Kue perut punai } \\
\text { 5. Bolu koja } \\
\text { 6. Bay tat } \\
\text { 7. Mie terbang } \\
\text { 8. Rendang lokan } \\
\text { 9. Sambal lokan } \\
\text { Makanan hidangan khas } \\
\text { 1. Rendang lokan } \\
\text { 2. Sambal lokan } \\
\text { 3. Gulai kepala ikan } \\
\text { 4. Sate mie }\end{array}$ \\
\hline $\begin{array}{l}\text { Curup/Rejang } \\
\text { Lebong }\end{array}$ & $\begin{array}{ll}\text { 1. } & \text { Wisata taman } \\
\text { bunga } \\
\text { 2. } \\
\text { Danau Harun } \\
\text { Bastari } \\
\text { 3. Suban air panas } \\
\text { 4. } \text { Bukit kaba } \\
\text { 5. Bunga Raflesia } \\
\text { Arnoldi } \\
\text { 6. Air terjun kepala } \\
\text { 7. Kebun binatang } \\
\text { Diobagitte } \\
\text { 8. Air terjun sindang } \\
\text { kelingi } \\
\text { 9. Telaga putri tujuh } \\
\text { warna }\end{array}$ & $\begin{array}{l}\text { Oleh-oleh khas } \\
\text { 1. Marning asin } \\
\text { 2. Marning manis } \\
\text { 3. Marning balado } \\
\text { 4. Pisang selai panggang } \\
\text { keju } \\
\text { 5. Pisang selai coklat } \\
\text { 6. Keripik ubi ungu } \\
\text { 7. Pisang selai goreng } \\
\text { 8. Keripik pisang asin } \\
\text { 9. Keripik pisang manis } \\
\text { 10. Keripik bayam } \\
\text { 11. Keripik salai gulung } \\
\text { 12. Rengginang ketan } \\
\text { hitam } \\
\text { 13. Rengginang ketan putih } \\
\text { 14. Kacang kulit goreng } \\
\text { 15. Buah strawberry } \\
\text { 16. Dodol terong } \\
\text { 17. Dodol papaya } \\
\text { 18. Dodol perenggi } \\
\text { Makanan hidangan khas } \\
\text { 1. Lemea } \\
\text { 2. Aneka sayur rebung } \\
\text { manis } \\
\text { 3. Aneka sayur rebung } \\
\text { asam }\end{array}$ \\
\hline Kaur & $\begin{array}{l}\text { 1. Pantai way hawang } \\
\text { 2. Pantai laguna } \\
\text { 3. Pantai linau } \\
\text { 4. Pantai sekunyit } \\
\text { 5. Pantai teluk beringin } \\
\text { 6. Air terjun tujuh } \\
\text { tingkat }\end{array}$ & $\begin{array}{l}\text { Oleh-oleh khas } \\
\text { 1. Kue tat } \\
\text { 2. Gula aren } \\
\text { 3.Kue cucur beras } \\
\text { 4. Keripik gurita } \\
\text { 5. Sate gurita } \\
\text { Makanan hidangan khas } \\
\text { 1. Gulai ikan mukus } \\
\text { 2. Bagar hiu } \\
\text { 3. Pendap } \\
\text { 4. Rebung asam } \\
\text { 5. Sayur terung unji } \\
\text { 6. Gulai tempoyak } \\
\text { 7. Kelicuk tapai } \\
\text { 8. Lemang tapai } \\
\text { 9. Gulai humbut } \\
\text { 10. Sambal petai } \\
\text { 11. Gebung asam ikan } \\
\text { 12. Gulai ikan baaung } \\
\text { 13. Sate gurita }\end{array}$ \\
\hline
\end{tabular}

Sumber: Peneliti (2019) 
Lingkungan yang dihadapi oleh para pelaku usaha kuliner di Provinsi Bengkulu terdiri dari lingkungan eksternal dan lingkungan internal, lingkungan eksternal biasanya sangat sulit dikendalikan. Termasuk didalamnya adalah adanya ancaman dan peluang usaha yang muncul dari pihak lain. Sedangkan lingkungan internal adalah faktor pendukung dari dalam termasuk diantaranya dukungan dari pemerintah setempat.

Tabel 3. Faktor eksternal dan internal potensi usaha kuliner di Provinsi Bengkulu

Faktor eksternal

\section{PELUANG}

1. Keuntungan yang tidak terbatas

2. Kemudahan regulasi dalam mendirikan usaha

3. Bahan baku yang berlimpah

4. Bertambahnya destinasi wisata yang baru

5. Bertambahnya jumlah wisatawan yang berkunjung

6. Lingkungan usaha dan pemerintah yang sangat mendukung

7. Makanan masih menempati urutan bisnis yang menjanjikan dan diminati masyarakat.

\begin{tabular}{ll}
\hline ANCAMAN \\
\hline 1. & Persaingan produk sejenis yang semakin variatif \\
\hline 2. & Produk sangat mudah ditiru \\
\hline 3. & Penggunaan modal usaha yang tidak tepat. \\
\hline 4. & Kunjungan wisatawan yang berkurang. \\
\hline 5. & Keamanan dan lingkungan yang tidak kondusif. \\
\hline 6. & Banyaknya produk kemasan yang sama di modern \\
market.
\end{tabular}

Factor eksternal

KEKUATAN

1. SDM yang berlimpah

2. Inovasi sangat bisa diulakukan dalam kemasan maupun pengolahan

3. Modal yang tidak terlalu besar

4. Tehnologi informasi yang berkembang pesat

5. Sarana promosi yang sangat mudah

6. Dukungan pemerintah yang sangat besar.

7. Produk makanan digemari masyarakat.

KELEMAHAN

1. Desain produk yang kurang menarik

2. Kapasitas tempat usaha yang kurang memadai

3. Kurangnya SDM yang berkualitas

4. Pelayanan yang tidak profesional

5. Tidak menjaga kebersihan lingkungan

6. Kurangnya promosi usaha

7. Harga jual yang tidak mampu bersaing

Sumber: Peneliti (2019)
Dari data-data yang ada, akan di cari bobot, rating dan skor dari faktor internal maupun eksternal, sehingga akan diperoleh produk makanan apa yang memberikan peluang usaha terbesar dan berdampak pada peningkatan pariwisata di Provinsi Bengkulu.

\section{KESIMPULAN DAN SARAN}

Dari informasi yang di peroleh, maka dapat disimpulkan bahwa wisata kuliner Provinsi Bengkulu mempunyai prospek yanga sangat bagus untuk di kembangkan, dengan memaksimalkan kekuatan yang ada, mengatasi ancaman yang datang dan para pengusaha dapat menangkap peluang maka kelemahan yang ada dapat dicari solusi terbaik untuk mengatasinya.Pemerintahpun sangat mendukung perkembangan usaha kuliner, karena pemerintah menyadari tanpa usaha kuliner sebaik dan sebagus apapun tempat wisata, tidak akan dapat menunjang perkembangannya.

\section{REFERENSI}

[1] E. Mulyana, "Upaya Pemberdayaan Ekonomi , Sosial dan Budaya pada Masyarakat Melalui Pengembangan Bisnis Ekowisata," vol. 1, no. 1, pp. 38-43, 2019.

[2] Sugiyono, Metode Penelitian Kuantitaif, Kualitati, dan $R \& D$. Bandung: Alfabeta, 2013.

[3] Suryana, Kewirausahaan, Pedoman Praktis,Kiat dan Proses Menuju Sukses, 4th ed. Jakarta: Salemba Empat, 2008.

[4] R. Setiawan, "Faktor-Faktor yang Mempengaruhi Permintaan Jasa Pariwisata Pemandian Air Panas," vol. 1, no. 1, pp. 5361, 2019.

[5] Samuel Hatane, "Pengaruh Stimulus Media Iklan, Uang Saku, Usia dan Gender terhadap prilaku pembelian Impulsif (Studi Kasus Produk Wisata)," 2007.

[6] DPR, Undang-Undang. 1990.

[7] Arikunto, Prosedur Penelitian. Suatu Pendekatan Prakti. Jakarta: Rineka Cipta, 2010.

[8] "Dinas Pariwitasa Provinsi Bengkulu." [Online]. Available: http://pariwisata.bengkuluprov.go.id. 